\title{
A Service Improvement project of a Legacy Nurse Programme to improve the retention of late career nurses.
}

\section{Abstract}

\section{Background}

A Nottingham Legacy Nurse Programme was developed in response to the reducing supply of new nursing registrants and an aging workforce. The programme comprised components of focused mentorship, knowledge transition, support and development of new learners in practice.

\section{Aims}

The work-based development programme aimed to improve the retention and experience of late career registered nurses.

\section{Methods}

The programme was informed by the evidence base and co-produced with late career registered nurses (aged 55 years or over, approaching retirement). A small pilot programme $(n=6)$ was evaluated through a mixed methods approach. Refinements and recommendations were proposed in response to findings of a scoping search of the literature, feedback from participants and stakeholder groups across the NHS Midlands and East regions ( $n=238$ ).

\section{Results}

A Legacy Nurse programme has potential to address nurses' individual career development needs, valuing and retaining them in the workforce, enabling them to share professional knowledge and skills within clinical teams and offers a costeffective solution to improving retention of late career nurses.

\section{Conclusions}

Addressing the needs of late career registered nurses is required to improve retention, job satisfaction, quality of care provision and facilitate knowledge transfer. The programme requires evaluation in other care settings and should be considered as part of an integrated approach to nurse retention, inclusive talent management and workforce planning, alongside financial and careers advice. 
KEYWORDS: Nurse retention, Late Career, Nursing education; Nursing roles; Management and leadership; Workforce and employment; Innovation and improvement

\section{Introduction}

Improving retention of the workforce is a critical priority facing health and social care globally, with concerns about an ageing nursing profession reported by many international nursing organisations. The International Centre on Nurse Migration, (Buchan et al., 2018) reported organisational factors which impact on nurse satisfaction and retention, including: the working environment, working relationships; financial and non-financial incentives; flexible working; career and educational opportunities; responsive management, effective supervision and focused mentoring; and job opportunities in different organisations, sectors, regions and countries. The World Health Organisation, International Council of Nurses and Burdett Trust for Nursing in the UK, launched the 'Nursing Now' campaign (2019), which highlights that, globally, nine million more nurses and midwives are needed by 2030 and action is needed to improve nurses' working conditions, training and leadership skills (Nursing Now https://www.nursingnow.org/).

In England, nursing shortages have been reported as the most urgent workforce priority facing the NHS, with 40,000 reported vacancies in substantive nursing posts (NHS England, 2019b). The UK-wide Royal College of Nursing (RCN) employment survey 2019 identified that nearly a quarter of nurses and midwives were looking for a job outside the NHS (2019). Almost a third of qualified nursing, midwifery and health visiting staff in the UK are over 50 years old, with one in three nurses due to retire in the next ten years (Nursing and Midwifery Council, 2017; Jones et al., 2015; King's Fund, 2018). The Royal College of Midwives (RCM) (2017) warns that one in three registered midwives in the UK are now over 50 years of age (NHS Digital, 2019). In a survey of 1,626 nurses who left the professional register in the UK between November 2018 and June 2019, retirement (52.7\%) was identified as the top reason (Nursing and Midwifery Council, 2020). The average age of leaving the professional register has reduced steadily from an average of 55 years of age in 2013 to 51 years of age in 2017 (Nursing and Midwifery Council, 2017). 
The nursing workforce crisis has only been further exacerbated as a result of the Covid -19 pandemic, with ongoing inequalities, increasing workforce pressures and challenging working conditions (Borneo et al., 2020). Following the first phase of the response to the Covid-19 pandemic, the importance of a culture of compassionate and inclusive leadership which prioritises staff retention, health and wellbeing has been identified as essential to enable staff to carry out their work caring for others (Bailey and West, 2020) and this is central in the NHS People Plan for 2020-21 (NHS England, 2020). There is an even greater emphasis and focus required on the retention of a workforce experiencing unprecedented pressures. West and Dawson (2012) describe three core 'ABC' human work needs to ensure nursing and midwifery wellbeing and motivation at work, and to minimise workplace stress: autonomy, belonging and contribution.

Managing a multi-generational team requires managers and organisations to adopt a more flexible approach to work organisation, task management and duty rotas (NHS Employers, 2017). Requests to work flexibly, part time and in job-share are common among the older workforce (Royal College of Nursing, 2016). Working flexibly may enable older nurses and midwives to work to the top of their potential, with longer recovery periods and more time to manage other family or carer responsibilities. The NHS Working Longer Review (University of Bath and The NHS Staff Council, 2014) identified that organisations can enable nurses to retain employment by providing early intervention services (occupational health services, physiotherapy or counselling), discussing and planning with staff themselves to identify the measures they need to help them to work in clinical settings. Helping staff to make plans for their future career and retirement at an early stage will facilitate retaining older workers and enable them to work effectively (NHS England, 2019b; NHS Employers, 2017).

The House of Commons Health Committee Report (2018) identified that a reduction in the availability of post-registration funding for training and development was a major issue contributing to nurses leaving the profession. In addition, newly qualified staff have reported the pressures of challenging working environments, when experienced staff do not have time to support them adequately. Lack of recognition, esteem and low rewards have been identified across Europe as the main reasons for nurses of all ages leaving the profession (Li and Jones, 2013). The Working Longer 
Review (University of Bath and The NHS Staff Council, 2014) identified that older workers in particular often feel undervalued and not respected by managers and colleagues. The 'Mind the Gap' Report (Jones et al., 2015) highlighted that appreciating each generation for the strengths they bring to the team facilitates a higher level of team performance. The RCN (2016) recommend the introduction of a learning strategy, providing midlife development reviews for career planning with psychological and financial planning. Interventions are required to develop the skills and knowledge of managers in their role in supporting an older workforce.

\section{Regional Context}

As one of a number of nurse retention initiatives underway across the East Midlands region of England, this pilot programme aimed to develop a greater understanding of the needs of late career nurses and implement innovative supporting strategies to help organisations retain experienced staff. The East Midlands region is a diverse area covering six counties with 15 NHS trusts covering $12 \%$ of the total area of England with a population of 4.8 million. The area hosts significant conurbations such as Nottingham and Leicester with $29.5 \%$ of people living in rural areas. In relation to other regions of England, the East Midlands has lower levels of deprivation although it was estimated that $18.5 \%$ of the population still lived in areas classified as being in the most deprived quintile in England (2016 data). The area has an ageing population with life expectancy at birth for males and females significantly lower than England as a whole (Public Health England, 2018).

\section{The Nottingham Legacy Nurse Programme (NLNP) Pilot}

The programme was developed and led by the Institute of Care Excellence at Nottingham University Hospitals NHS Trust, on behalf of the local integrated health and social care system's professional nursing and midwifery cabinet (a group of senior nurse and midwife leaders representing organisations and stakeholders from within the local care system). It was identified that retaining the professional knowledge and skills of experienced nurses was an essential local workforce priority. Nationally within the NHS, workforce planning has traditionally been focused on supply and pipeline to increase nursing student numbers, rather than investigating and evaluating how experienced nursing knowledge is valued and retained. Retention of the workforce is critical due to global nursing shortages, reductions in supply of new nurses coming into the profession and an increasing number of 
learners within the practice environment. In the NHS this includes clinical apprenticeships, new roles and a strategic intention to retain and expand student numbers and placement capacity (Health Education England, 2018). In addition, registered nurses who work in the NHS on the 1995 NHS pension scheme are eligible to retire at 55 years old. Within an increasingly stressful workplace and as a result of the pandemic there is a risk that more will choose to leave (King's Fund, 2020).

The programme of work was funded by Health Education England (East Midlands) through the region's Nursing Supply and Demand Programme Board. This regional Board of Nurse Directors was established in 2016 to advance work on nursing workforce supply and retention across the region. An independent evaluation was undertaken as part of an Economic and Social Research Council Impact Leaders award. The programme was inspired by the Legacy Mentor project conducted by Clauson et al. (2011). The title of Legacy Nurse resonated with the aims of the programme, facilitating a way for registered nurses to develop and share their wealth of expertise with future nursing generations. The programme objectives were to:

- Evaluate the potential benefits of an innovative mentorship model.

- Identify ways to facilitate the translation of nurses' expertise.

- Explore ways to improve retention of the late career nursing workforce.

- Explore how the programme mechanisms can impact the practice learning environment.

This paper presents the stages of Nottingham Legacy Nurse Programme (NLNP) development, pilot testing, implementation and phase two wider stakeholder engagement and evaluation.

\section{Methodology}

The service development followed four stages outlined in the RE-AIM framework (Glasgow et al., 2019) to help plan the NLNP and consider the programme sustainability, adoption and implementation: Reach; Effectiveness; Adoption; Implementation. The programme objectives were addressed by:

1. completing a pilot programme

2. conducting a scoping review of the literature 


\section{3. concept mapping of a NLNP}

4. developing recommendations for the next stage of the programme including wider stakeholder engagement and recommendations for implementation.

The pilot programme, scoping study and stakeholder feedback stages of the programme were conducted concurrently with quantitative and qualitative data collated and synthesised to produce overall findings and recommendations for the next stage of the programme (Creswell et al., 2004).

\section{The Pilot programme}

The Nottingham Legacy Nurse Pilot Programme ran from December 2017 - June 2018. Six nurses who submitted expressions of interest and had the support of their nursing managers were recruited. The Legacy Nurses were employed by three different organisations including NHS and social care providers in the region. Legacy Nurses worked in different settings, including acute and surgical care, healthcare of the older person, community nursing, school nursing and outpatient clinics.

The initial programme was based on the Legacy Mentor project conducted by Clauson et al. (2011) and consisted of two introductory days, one day per week in clinical practice to complete project work, one workshop per month and individual coaching as required with the programme facilitator. A practice development nurse, skilled in coaching techniques facilitated the programme. The Legacy Nurses had individual meetings with the facilitator to discuss and co-produce their individual 'needs led' development plan and project objectives.

\section{Work Based Educational Improvement Projects}

Legacy Nurses were asked to consider their professional knowledge and expertise to develop their own improvement projects focused on the needs of their clinical area. This aimed to recognise and value the wealth of participants' professional nursing experience and utilise the opportunity for knowledge transition to other members of their team, including new starters and other learners. Group workshops enabled Legacy Nurses to explore project ideas and receive peer support and advice. The projects included:

- Acute care and older people: an intervention focusing on staff education and raising awareness to improve bowel care assessment, management and 
documentation. The project also aimed to improve referral processes to specialist teams. The Legacy Nurse developed an education resource for the clinical area. The project identified savings through more efficient and targeted use of clinical supplies.

- Community nursing: the project initially scoped the emerging priorities for staff retention. To support retention an intervention was developed to support new staff which included: a contacts pocket book; induction documentation package; key policies and skills development; support and training from experienced staff in complex clinical tasks, information databases and use of specialist equipment.

- Acute surgical care: the project reviewed the needs of the aging clinical nursing workforce and retirement support and evaluated the impact on retaining nursing staff and nurses returning to practice.

- First responder in community care: the project provided preceptorship to new community lone working nurses. The project reduced the time required for new nurses to achieve competency in their role.

\section{Results: Pilot Programme Evaluation}

The NLNP was evaluated using a longitudinal mixed-method approach which included: pre- and post-programme self-report skills assessment and qualitative interviews conducted pre- and post-programme. The interviews were transcribed, transcription checked against recordings, and then analysed thematically. This involved a process of coding for meaning and content, and then building themes by linking groups of codes together. This was done by one researcher (ST) and the initial analysis checked and agreed at a meeting of the project team.

The study sample included all nurses who participated in the pilot programme (December 2017 - June 2018). Five of the six participants completed the programme. One participant left the programme due to new employment. Participants reported a $28 \%$ improvement in their skills assessment (networking; project planning; knowledge of implementation process; managing change and communication skills). Thematic analysis in the interview data revealed the following themes: wealth of experience; energised; community of practice, protected time

\section{Wealth of experience}


Nurses who participated in the NLNP programme had developed specialist skills and experience in a variety of clinical settings. Before starting the programme, they were keen to pass on their skills and identify ways to support this. Initially Legacy Nurses under-valued their expertise, but the programme enabled them to reflect and be aware of the wealth of their professional knowledge. The programme provided time for the Legacy Nurses to mentor students and newly qualified staff, and some had used their newly developed coaching skills to support existing staff members in their clinical areas.

\section{Energised}

The Legacy Nurses described feeling energised by the programme. They had learnt new skills which they were able to apply in practice and as a result said they felt more confident. The Legacy Nurses enjoyed learning new things and found the improvements they made in practice through their individual projects very rewarding and many planned to continue developing their projects after the end of the programme. The programme was seen as a way of addressing a lack of a formal career path for experienced clinical nurses.

\section{Community of practice}

Having the time, space and support to complete the programme was described by participants as very important to the success of the programme. Group workshops away from busy clinical areas facilitated the cohesion of the group and expert facilitation provided guidance and support. All of the Legacy Nurses valued the peer support components of the programme and planned to continue meeting as a group.

\section{Protected time}

Initially, the Legacy Nurses encountered difficulty in safeguarding time to complete the programme. The facilitator offered support by communicating the programme objectives with clinical managers, although some clinical areas still struggled to release staff during busy periods.

\section{Scoping review}




\section{Methods}

To map the existing evidence reporting the views and experiences of late career nurses a scoping study (Arksey and O'Malley, 2005) was completed in April 2018. The aim of the review was to identify the existing literature about the retention and recruitment of late career nurses. The PCC framework (Population, Concept, Context) (Aromataris and Munn, 2020) was developed to define the scope of inquiry and inform the initial eligibility criteria for inclusion (Levac et al., 2010).

- Population: registered nurses, healthcare managers and commissioners.

- Concept: Retention and recruitment of late career nursing staff. Nurses approaching retirement or already retired.

- Context: Health and social care organisations in countries with similar structures of nursing care to the UK.

A literature search was undertaken using MEDLINE, CINHAL and The Joanna Briggs Library databases from the January 2000 to April 2018. The search included all primary research studies, policy and systematic reviews published in the English Language. The scoping search was restricted to three key databases and did not include a grey literature search due to the practicalities of time and resources. Data were extracted using a pre-designed data extraction form, designed to address the scoping review objectives; 1) To identify existing interventions to support late career nurses; and 2) To identify the views and experiences of late career nurses. Data included: publication year and country where the study was performed: the study design; aims; characteristics of participants and setting; intervention or phenomena; research method; findings and authors' conclusions. A table of the included studies was presented followed by a narrative description of the literature. A thematic analysis was conducted, data were categorised into initial themes. Engagement events were held with key stakeholders including participants in the pilot programme, the legacy pilot lead nurse, the nursing workforce development lead and a health services management researcher. Initial themes were presented and discussed with the stakeholders to reach consensus on the final themes and inform the reporting of the findings (Arksey and O'Malley, 2005). 


\section{Findings}

The search identified 1,970 papers which were screened by a single reviewer on the information provided in the title and abstract. Papers which did not meet the inclusion criteria were excluded $(n=1926)$. Forty-four papers were retrieved, and full text assessed by two reviewers, 15 papers were excluded (did not meet inclusion criteria), and 29 papers were included. There were 24 primary research studies (Table 1).

The findings reported in the included studies were reported narratively. This process was completed separately for the qualitative and quantitative studies. Data from qualitative and quantitative studies were then synthesised into key themes. Two overarching themes identified were: 1 . What late career nurses need to help them make choices about continuing to work; 2 . What late career nurses need to help them continue working

\section{What late career nurses need to help them make choices about continuing to work}

\section{Information}

Some nurses reported a lack of knowledge about the impact on their pensions if they continued working and needed individualised financial information to help them make decisions about how and when to retire (Andrews et al., 2005; Blakeley and Ribeiro, 2008; Storey et al., 2009; Watson, 2003).

\section{Value and recognition}

Feeling undervalued in their current role was reported as a reason for deciding to retire from nursing. Conversely when nurses perceived that their skills and experience were valued by employers, they felt more positive about continuing to work (Blakeley and Ribeiro, 2008; Clendon and Walker, 2016; Jeffs et al., 2014; Ryan et al., 2017; Storey et al., 2009; Uthaman et al., 2016). Formal feedback on job performance was important to nurses. This feedback helped them make decisions about whether to retire or continue working (Jeffs et al., 2014; Palumbo et al., 2009).

\section{Training and opportunities}

Older nurses wanted more support with the introduction of new technology (Valencia and Raingruber, 2010). Nurses reported feeling burdened by the need to keep up-todate with professional training and to undertake academic education (Blakeley and 
Ribeiro, 2008; Clendon and Walker, 2016). However, some nurses would welcome the opportunity to undertake professional development, complete training to enable them to work in different settings as they reported that they have limited options for the work they were able to undertake (Andrews et al., 2005; Clendon and Walker, 2016; Uthaman et al., 2016).

\section{What late career nurses need to help them continue working}

\section{Flexible working patterns}

Some nurses reported that they chose to retire at the same time as their partners, other reasons included wanting to spend time with their families or to undertake family caring responsibilities (Durosaiye et al., 2016; Andrews et al., 2005; Uthaman et al., 2016; Watson, 2003). Shift work and working long hours were reported to negatively impact on family roles and social functioning (Durosaiye et al., 2016; Graham et al., 2014; Letvak, 2003a; Uthaman et al., 2016). The availability of flexible work patterns which accommodated nurses' caring responsibilities was an incentive to remain in employment (Utriainen et al., 2015). While shift work has been reported as preferable for some older nurses, many nurses wanted to be able to choose the number of hours and days they worked (Andrews et al., 2005; Clendon and Walker, 2013b). Many nurses reported they felt more fatigued from working night shifts as they got older and had chosen to reduce their hours (Andrews et al., 2005; Blakeley and Ribeiro, 2008; Dziadekwich et al., 2012; Graham et al., 2014; Letvak, 2003b; Spiva et al., 2011; Uthaman et al., 2016).

\section{Financial incentives}

Nurses reported that financial security was a reason for deciding to retire.

Conversely financial incentives also influenced nurses' decision to remain in work (Blakeley and Ribeiro, 2008; Duffield et al., 2015; Clendon and Walker, 2016; Letvak, 2003b; Uthaman et al., 2016).

\section{Supportive environments}

Social / peer support: Nurses in the included studies reported enjoying patient contact and the camaraderie and support from colleagues (Liebermann et al., 2015; Uthaman et al., 2016). However, nurses also reported feeling guilty about their 
decreased ability to cope with heavy workloads, as they did not want to let their colleagues down (Clendon and Walker, 2016). Generational conflicts and staff shortages were also reported as barriers to continuing employment into nurses' late careers (Letvak, 2003a; Letvak, 2003b).

Physical support: Older nurses wanted the option to work in areas which had lighter workloads and a less stressful environment. Nurses expressed fears about cognitive ability and their physical fitness. Studies suggested that the physical and cognitive demands of the job could be improved by having ergonomically designed workplaces including availability of lifting aids; ergonomic computer workstations; softer floors; reducing the distance nurses need to walk to access equipment (Stichler, 2013; Uthaman et al., 2016).

\section{Concept mapping and refining the programme design}

The conceptual framework for the NLNP was informed by the feedback from participants of the pilot programme and the scoping review. Initial theories and concepts were identified which were then further tested through wider engagement with stakeholder groups. Potentially beneficial mechanisms of change were identified (Table 2) with additional consideration of how the NLNP could maintain process fidelity, whilst providing flexibility to enable adaption to different contexts and settings (Novick et al., 2013). The format of the programme was outlined to define facilitator and participant characteristics and the programme design included key components. These were discussion groups, workshops, presentations, individual coaching support and methods of evaluation (Table 3 ). Participant feedback suggested that the programme runs for a minimum of 6 months with at least one day per week focused on individual project work. Provision of long-term projects has been suggested to improve the benefit of late career nursing initiatives, alongside an opportunity to select or design projects of interest to participants (Doran et al., 2015).

\section{Wider stakeholder engagement and recommendations for implementation.}

Consultations with stakeholder groups provided their views and feedback on the NLNP (Figure 1). Stakeholders were identified from across the NHS Midlands and 
East regions via social media platforms and email networks. Feedback from an online questionnaire was obtained from nursing and midwifery leaders and managers; healthcare public bodies; clinical nurses and midwives; clinical educators; practice development teams and higher education institutions $(n=238)$. The stakeholder groups were asked for their views about the needs of the late career workforce, their thoughts and interest in relation to the NLNP, ideas for potential projects and ways to engage the late career workforce.

Clinical nurses and midwives $(n=190)$ reported they wanted opportunity to access training and development opportunities as their careers progressed, however older nurses and midwives sometimes felt overlooked. Flexible working contracts were defined in various ways: retire and return; shorter shifts; reduced working hours; part-time work; reduced responsibility; no requirement for night duty; fixed duty rotas; and breaks between working days. However many respondents reported similar benefits of flexible contracts which were said to help cope with the physical and psychological demands of the job, helping staff to fulfil caring responsibilities for family members, achieving a better work-life balance and to providing an income in late careers.

Many respondents reported feeling undervalued by colleagues and managers. Older nurses and midwives wanted greater recognition of their knowledge, skills and expertise, dedication and compassion. Some respondents said they had received conflicting advice about their pensions, some were unsure about the financial impact of retire and return contracts. When staff had tried to access retire and return contacts, they found the process complicated and time-consuming. The NLNP received favourable feedback from respondents who identified the potential to support both junior and more experienced staff in the next steps of their careers and improve retention. Respondents identified two main advantages: the potential to improve job satisfaction and enable the transfer of knowledge and skills of experienced nurses and midwives to the next generations. However, some respondents raised concerns about the feasibility of the NLNP, in particular being released from their clinical duties given that services are already overstretched. Nursing and midwifery managers and clinical leaders $(n=48)$ identified that late career nurses and midwives have knowledge, skills, experience, maturity and 
resilience which are highly valuable to the workforce and supporting more junior staff. Respondents recognised the need to re-energise late career nurses and midwives and provide opportunities for them to take up new roles, flexible working or to undertake training. Most respondents would be very interested in taking part in a future programme and some leaders were already developing their own programmes within their organisations. Respondents expressed a need to develop effective ways for late career staff to share their expertise within clinical settings and enhance the skill mix in clinical teams. Clear guidance on facilitating late career flexible employment contracts and training frameworks for late career staff were also identified as important components for improving retention of late career staff. The need to engage with late career nurses and midwives before they start making retirement plans was highlighted. Late career programmes and opportunities need to be promoted in good time to ensure nurses and midwives continue to feel motivated and valued.

\section{Findings of NLN programme}

The pilot evaluation and stakeholder feedback identified that the NLNP should be considered alongside a strategic approach to career planning, inclusive talent development and staff retention of the later career workforce (Figure 2). This supports the recommendations of the International Centre on Nurse Migration report (Buchan et al., 2018), which highlights that linking numerous policies and interventions in 'policy bundles' is likely to be more effective than single interventions for improving staff retention. The impact of the pilot programme was identified across three levels:

- The Individual: feeling re-energised, confident and appreciated; learning new skills; developing supportive networks; leading to new career opportunities

- The Clinical areas: impact of the Legacy Nurse projects (improving quality and patient experience, training and knowledge transfer; supporting the wider team; appropriate use of resources (project work)

- The Organisation: Knowledge Translation across specialties and NHS Trusts; improving retention of late career staff 
The RE-AIM framework (Glasgow et al., 2019) was applied to the NLNP to help consider how the programme could be evaluated and implemented in wider healthcare settings and professions (Table 4).

\section{Discussion}

The aim of the pilot programme was to develop, pilot test and refine a Legacy Nurse programme to improve the retention of the late career workforce in nursing and enhance professional knowledge translation into the clinical learning environment. In addition to achieve these aims, a scoping study and stakeholder feedback identified components of a programme which had the potential to improve retention and the quality-of-care provision. The theory underpinning the proposed programme components was explored to identify the mechanisms needed to achieve the desired outcome: energise and empower staff, develop supportive networks, facilitate knowledge transition, improve clinical outcomes and patient experience, create learning environments and career opportunities and improve the psychosocial and physical wellbeing of late career nurses.

Participants in the pilot NLNP took the lead, initiating their ideas for professional knowledge transfer and service improvement, utilising a bottom-up distributed leadership approach (Thorpe et al., 2011). Front line practitioners had protected time to learn, develop, implement change and share knowledge with others in practice. They articulated pride in their profession and positive emotions associate with the Legacy Nurse role. Pride and joy at work have been identified as central to workforce retention (NHS Improvement, 2016) and involves engaging a workforce with a positive attitude toward their organisation and its values, impacting positively on patient experience and outcomes (Perlo et al., 2017).

The NHS Staff Survey in England (NHS England, 2019a) identified that nurses and midwives who had opportunities to show initiative and make suggestions to improve their workplace had higher levels of work engagement. West et al. (2020) highlighted core workplace needs to enable nurses and midwives to deliver high-quality care: 1 ) autonomy - need for control over our work lives, acting consistently with work and life values; 2) belonging - to be connected to, cared for, and caring of others in the workplace. Feeling valued, respected and supported; 3) contribution - to experience 
effectiveness and deliver valued outcomes. The factors identified by West et al. (2020) were reflected in the NLNP evaluation, in particular, the concepts of connecting with fellow participants and feeling valued for their knowledge and experience were strongly expressed and valued by the participants in the pilot NLNP.

The impact of the NLNP pilot on individual, clinical and organisational outcomes demonstrate the potential of the programme to benefit the wider workforce if they are implemented within a range of multi-level strategies over a sustained period of time. Any programme of development must operate from within the organisational culture in which it is situated. In England, the NHS is facing unprecedented challenges following the first and second waves of the Covid-19 pandemic. Pressures on the NHS have been compounded and exacerbated by longstanding issues including chronic excessive workload, inadequate working conditions, staff burnout and inequalities, particularly among minority ethnic groups (King's Fund, 2020). Institutional racism has been exposed despite the NHS having one of the most ethnically diverse workforce (Ross et al., 2020). Lack of staff development and supportive networks have been highlighted as barriers to career progression and contribute to negative experiences of ethnic minority NHS staff. Therefore, a central consideration for future programmes is ensuring access and inclusion of late career nurses from ethnic minority backgrounds. Organisations need to make a concerted effort to retain and value the professional knowledge and experience of registered nurses who face discrimination and challenges at a disproportionate rate to their white colleagues (Ross et al., 2020).

\section{Limitations}

This was a small pilot study which only included six nurses so the findings may not be transferable to nurses in different contexts. However, further consultation from 238 stakeholders was sought to inform the recommendations. As part of the implementation plan, a larger evaluation is required in different sites and settings to identify how the programme performs and the refinements and adaptations needed for different settings and participants. Although the pilot only lasted six months, all participants continued to receive mentorship to help their transition back into practice areas and identify career development opportunities. 
Wider implementation (phase 2) is now underway across the local integrated health and social care system to include wider care settings, nurses, midwives and allied health care professionals. Recognising the context, post first and second wave of the Covid-19 pandemic and the additional work stressors on staff, further stakeholder engagement is underway to assess the impact of the pandemic on late career healthcare professionals and their career intentions. This includes impact on the health and wellbeing of staff, alongside workforce performance, retention outcomes and further consideration of sustainable supportive interventions.

\section{Conclusion}

A pilot programme was developed and evaluated in a small cohort of Legacy Nurses and independent evaluation was positive from the nurse participants, managers and facilitators. Programmes aimed at retaining late career nurses are already being implemented in various healthcare settings internationally. However, there is a lack of evidence-based programmes and the need for further evaluation and an effective and sustainable programme. The components of communities of practice, engagement and coaching have the potential to address late career nurses needs and enable them to share their professional knowledge and skills within clinical teams.

The critical nursing workforce context has been further exacerbated by the Covid-19 pandemic. To address the need for restoration and recovery and the workforce required for transformation to deliver on the NHS Long Term Plan (NHS England, 2019c), employers are seeking to adopt new roles and flexible ways of working to retain nurses. There is an even greater requirement to focus on the retention of a workforce who have experienced unprecedented pressures. The NLNP was seen by the participants as a way of addressing a lack of a formal career path for experienced clinical nurses. The information from the evidence base, stakeholder engagement and the underpinning theory of the supporting mechanisms for late career nursing was accessed to make recommendations for the components of a Legacy Nurse programme, with a recommendation that this model should be further tested and expanded to include midwives and other allied health care professionals in different healthcare contexts. 


\section{Key Points}

- Retaining late career nurses and midwives within health and social care is a critical global workforce priority.

- The NLNP has the potential to provide an innovative solution to workforce retention; recognising, valuing and retaining professional clinical knowledge and skills.

- In light of the first and second wave of the Covid-19 pandemic, additional stressors now facing the health and social care workforce and the potential impact on retention requires further research

- The programme requires further development in the post Covid-19 restoration and recovery phase, with wider testing and evaluation in various clinical settings. It should be considered as part of an integrated approach to workforce planning and inclusive talent development.

- To support late career nurse retention and the NLNP, an informed and more consistent approach to providing financial and pensions advice is required to support nurses and midwives considering their employment, flexible working or retirement options.

- Opportunities for career planning should be introduced and encouraged in early careers and revisited throughout the nursing career pathway.

\section{Ethical permissions}

The programme was agreed to meet the criteria for a service development/quality improvement project and ethical permission was not required.

\section{Acknowledgements}

This paper reports part of a project funded by NHS Health Education East Midlands and the Economic Social Research Council. 


\section{Figure captions}

Figure 1: Legacy Nurse stakeholder engagement schedule

Figure 2. Structures to support the Late Career Healthcare Workforce 


\section{Table 1. Data extraction from the studies included in the scoping review}

\section{Cross sectional surveys}

\section{Author}

(Year)

Blakeley and

Ribeiro

Canada

To explore the factors that influence

nurses to retire early and the incentives

in employment

\section{Clendon and To examine the views and characteristics}

of nurses working in New Zealand who

(2013a)

were born before 1960. (focus on the

Zealand

experiences of such nurses who undertake shift work)

\begin{tabular}{l|l} 
Doran et al. & To evaluate the impact of the late career \\
nurse initiative
\end{tabular}

(2015) their work environment, workplace burnout, job satisfaction, organisationa commitment and intention to remain.

Duffield et al. To identify factors that motivate older (2015) nurses to leave the workforce.

nures to

\section{\begin{tabular}{|l|l}
\hline Falk et al. & To examine the factors that relate to
\end{tabular}}

(2017) Nurses Practitioners, aged 55 years and

US older, and their intent to retire within 5

years.

\begin{tabular}{l|l} 
Liebermann & To identify job-related resources whic
\end{tabular}

et al. (2015) strengthen nurses' expectation of

Germany remaining in the same job until retirement age.

Kovner et al. $\quad$ To examine the characteristics and work less than age 50 and compare among the ere nursing, working outside wursing, and not working. \begin{tabular}{l|l} 
Palumbo et & To explore rural RNs' perceptions of intent \\
al. (2009) & to stay in their current position, with their
\end{tabular} al. (2009) us organization, and employment as a nurse

Storey et al. $\quad$ To examine issues associated with the \begin{tabular}{l|l} 
(2009) & impact of age on the retention of female \\
UK & primary and community care nurses in the
\end{tabular} National Health Service in England.

\section{\begin{tabular}{l|l} 
Type (number) or & Summary of the findings \\
participants
\end{tabular}}

45 years and

older $n=124$

\section{op reasons for wanting to retire early: E}

Top incentives to postpone retirement: Acknowledged for their work; take summer holidays; senior recognition (managers); thinking time; make higher

contributions to pension; valued for knowledge; being in less stressful work setting; being empowered; lighter workload; support with new technology; choice of hours; having a voice

Nurses 50 years and

older $\mathrm{n}=3272$ work shifts and indicated that shift work has a negative impact on their health. Respondents adapted their lifestyle to manage the impact of shift work, while others identified substantial negative impacts on health, family and social functioning and practice. Nurses reported the impact of fatigue on their lives and a decreasing ability to cope with this as they age. Those for whom shift work is less successful suggested that moving to part time and more flexible hours is one means of coping. Respondents noted that having to work night shifts and short shift changes had an impact on their ability to cope with shift work an the resultant fatigue from disrupted sleep patterns. Employers who do not use fixed schedules should consider moving back to more fixed scheduling practices.

Nurses 55 years and

older $=902$

Late career nurse initiative $(\mathrm{LCNI}): 0.2 \mathrm{FTE}$ reduction Participation was associated with positive perceptions of their organisation's leadership and of their own sense of involvement in hospital affairs. However, the initiative did not impact levels of workplace burnout, organisational commitment or job satisfaction. Participation did not impact the nurses' length of service or intention to leave their current job.

Nurses 45 years and The mean age for leaving the workforce was 61.7 years. Key motivators were: financial considerations (40.1\%), primarily financial security; nurse health $(17.4 \%)$ and retirement age of partner $(13.3 \%)$

Conclusions. Older nurses are leaving the workforce prior to retirement or pension age, primarily for financial, social and health reasons, taking with them significant experience and knowledge. As financial considerations are important in older nurses' decisions to continue to work, increasing the age of retirement may retain them. Consideration will need to be given to ensure that they continue to experience job satisfaction and are physically and mentally able to undertake demanding work.

Nurse Practitioners 55 years and older $\mathrm{n}=3171$

Nurses aged 21-63

years $n=387$

of master's degree were associated with intent to retire. Being "very satisfied" with one's job was retare
with one's job and working in primary care were related to intending to retire for the NPs 55-59.

For all age groups, work-time control is positively related to vitality and indirectly fosters the expectation of remaining in the same job until retirement age. Middle-aged nurses' vitality benefits most strongly from colleague support and positively stimulates nurses' expectation to remain in their job until retireme ge, while supervisor support and colleague support do not encourage older nurses' expectation. Supervisors should foster nurses' expectation of remaining in the same job until retirement by providing age-specific work resources.

Registered nurses (RN)

The clear work setting and work attitude differences between older working and younger working RNs.

Older RNs think there are fewer job opportunities for them than for younger RNs, and that they are more committed to their organizations compared to the loung hNs. The health of older RNs was not as good as young (he The majority (58\%) planned to work as a nurse after retirement. Only $19 \%$ of the sample indicated that they do not plan to continue working as a nurse. Conversely, $4 \%$ plan to work full time as a nurse after retirement. The top three HR practices reported by respondents as important to their decision to remain in their organizations were (a) recognition and respect, (b) having a voice, and (c) receiving ongoing feedback regarding one's performance. These were ranked above compensation (rewards) and flexible work options.

Primary care and $n=485$

Older nurses were more likely than younger ones to report that their role had lived up to expectations. Issues important for older nurses were feeling valued and being consulted when change was implemented. Important factors encouragng nurses to stay were pension considerations, reduced working hours $n$ retirement, and reduced workload. For those with degree-level qualifications, enhanced pay was a factor encouraging retention. Nurses might leave in response to high administrative workloads, problems in combining work and family commitments, and lack of workplace support. Retirement and pensions advice were not widely available. 
Conclusion. Two-thirds of nurses were generally happy in their role, it is important to maintain this level of satisfaction throughout a nurse's working life. Nurses may consider leaving prematurely unless policy makers and managers ensure the working environment reflects the issues nurses consider to be

Summary of the finding

\section{Qualitative studies}

\begin{tabular}{|c|c|c|}
\hline $\begin{array}{l}\text { First author } \\
\text { Country } \\
\text { Year }\end{array}$ & Study aim & $\begin{array}{l}\text { Type (number) or } \\
\text { participants }\end{array}$ \\
\hline \multicolumn{3}{|c|}{ Qualitative studies } \\
\hline $\begin{array}{l}\text { Andrews et } \\
\text { al. (2005) } \\
\text { UK }\end{array}$ & $\begin{array}{l}\text { To explore the influences on employment } \\
\text { related decision making in respect of } \\
\text { nurses over } 50 \text { in the UK. }\end{array}$ & $\begin{array}{l}\text { Nurses } 50 \text { years and } \\
\text { older } n=84\end{array}$ \\
\hline $\begin{array}{l}\text { Clendon and } \\
\text { Walker } \\
(2016) \\
\text { New } \\
\text { Zealand }\end{array}$ & $\begin{array}{l}\text { To learn about older nurses' experiences } \\
\text { of career planning, allowing a greater } \\
\text { understanding of their personal } \\
\text { experiences, interpretations and } \\
\text { viewpoints. }\end{array}$ & $\begin{array}{l}\text { Nurses } 50 \text { years and } \\
\text { older } n=46\end{array}$ \\
\hline $\begin{array}{l}\text { Durosaiye et } \\
\text { al. (2016) } \\
\text { UK }\end{array}$ & $\begin{array}{l}\text { To explore the existing theoretical contexts } \\
\text { of the job and exvironmental demands of } \\
\text { the nursing profession in the NHS and to } \\
\text { investigate the impact of job and } \\
\text { environmental demands on older nurses }\end{array}$ & Older nurses $n=10$ \\
\hline $\begin{array}{l}\text { Friedrich et } \\
\text { al. (2011) } \\
\text { US }\end{array}$ & $\begin{array}{l}\text { To discover what rewards and inspires } \\
\text { seasoned nurses to continue to practice in } \\
\text { acute care after the normal age of nurse } \\
\text { retirement. }\end{array}$ & $\begin{array}{l}\text { Nurses } 62 \text { years and } \\
\text { older; nurses } 55-62 \\
\text { years } n=25\end{array}$ \\
\hline $\begin{array}{l}\text { Jeffs et al. } \\
\text { (2014) } \\
\text { Canada }\end{array}$ & $\begin{array}{l}\text { To explore perceptions with } \\
\text { implementation of the Late Career Nurse } \\
\text { Initiative (LCNI) }\end{array}$ & Nurse leaders $n=59$ \\
\hline $\begin{array}{l}\text { Letvak } \\
\text { (2003a) } \\
\text { US }\end{array}$ & $\begin{array}{l}\text { To explore health and ageing concerns } \\
\text { and self-care strategies of older nurses }\end{array}$ & $\begin{array}{l}\text { Nurses } 50-62 \text { years } \\
n=14\end{array}$ \\
\hline $\begin{array}{l}\text { Letvak } \\
\text { (2003b) } \\
\text { US }\end{array}$ & $\begin{array}{l}\text { To explore the experience of being an } \\
\text { older nurse }\end{array}$ & $\begin{array}{l}\text { Nurses } 50-62 \text { years } \\
n=11\end{array}$ \\
\hline $\begin{array}{l}\text { Spiva et al. } \\
\text { (2011) } \\
\text { US }\end{array}$ & $\begin{array}{l}\text { To investigate older nurses practicing } \\
\text { bedside nursing and to identify ways to } \\
\text { influence } \\
\text { older nurses to continue bedside practice }\end{array}$ & Older Nurses $n=18$ \\
\hline $\begin{array}{l}\text { Valencia and } \\
\text { Raingruber } \\
\text { (2010) } \\
\text { US }\end{array}$ & $\begin{array}{l}\text { To identify what motivates experienced } \\
\text { nurses to continue working and to consider } \\
\text { retirement }\end{array}$ & $\begin{array}{l}\text { ICU nurses } 31-49 \text { years } \\
\text { and } 50-65 \text { years } n=16\end{array}$ \\
\hline
\end{tabular}

Andrews et $\quad$ To explore the influences on employment UK nurses over 50 in the UK.

Talker and To learn about older nurses experiences

To explore the existing theoretical contex of the job and environmental demands of investigate the impact of job and

environmental demands on older nurses seasoned nurses to continue to practice in acute care after the normal age of nurse retirement.

\begin{tabular}{ll} 
Jeffs et al. & To explore perceptions with \\
\hline
\end{tabular} Initiative (LCNI)

Push and Pull factors for leaving / remaining in their jobs. Push factors: Pace of technological change; Stress, workload, pace of clinical setting; physical demands; income (nurses' salary in comparison to other professions), lack of RR resources for older nurses. Pull factors. Fexible working (job share, partMost nurses viewed their careers as opportunistic, taking opportunities as they arose and ensuring their choices fitted in with family. Most believed participation in formal career planning would have been helpful. A number felt they had not planned early enough for retirement - particularly financially. Divorce was noted as having a significant financial impact and was a primary contributor to nurses remaining in nursing beyond retirement age. Formal career planning should be avaliable for all nurses. Embedding career planning in organisational policy can benefit both employees and employers. For most participants, being a nurse was inextricably intertwined with their identity as a person. Opportunities should be provided for nurses nearing retirement move into roles that allow them to contribute to the profession and organisation in ways that recognise their skills and experience. Examples include mentoring, education and quality roles. Participants strongly identified with the profession of nursing and wanted to contribute their skill and experience to the profession and their communities both before and after retirement.

Working on the ward was most challenging for the older nurse, with physical and cognitive demands most prominent (moving and handling patients, caring for very sick patients). Fast pace of work was challenging, nurses experienced less mobility and independence due to age/disability which causes difficulties physical and cognitive peran constructs. Nurses axperienced peduced copitive acuity with age which was not always recognised. Shift work also impacted sleep recovery and mental performance. Environmental demands impacted physical, cognitive and sensory constructs of older nurses. Four themes emerged in phase one which inspire nurses to remain in active practice: 1) Attitudes and Experience (appreciation of learning, wealth of experience, workplace culture and love of nursing; 2) Retention Factors (includes both retention strategies such as flexible hours and less physical challenges at work

- Needs of Older Nurse (exercise mind and body, finances, camaraderie at work; 3 ) Unique contribution (sharing of experience and making a difference) Nurses 55-62 years worried about retiring due to musculoskeletal injury and expressed greater need to move to less physical and less pressured positions Projects include patient centred care initiatives; skin would prevention, family engagement; nurse education; preventing readmission; mentoring; enhancing work schedules.

It was important to have clear goals, scoped projects, accountability, monitoring and feedback. Matching expertise and interests in projects, recognition, respect and feedback on performance. Creating new career paths to value older nurses' skilis and knowledge and utilise their talents. Additional support was provided for computer skills and flexible conditions were leveraged. Older nurses feel more autonomous if they are involved in mentoring, committees,

forming policies to improve care.

Nurses reported a love of the job, they had a special status/ uniqueness and variety in their work. Not 'older' but more experienced and respected. Nurses reported a loss of endurance, less energy. Shift work was more difficult with mental slips/slowness on the job reported. Nurses reported stress related to being on call and scheduling which ingre (n) carses retained their love for nussin

of dedication and commitment, they wanted to carry their load (confident in their ability and were empowered to

Nurses highlighted generational differences in the workplace. Older nurses enjoyed being role models and valued for their expertise. Reported that patients were more critical now but appreciated having a more experienced nurse. Nurses reported positive relationships with managers and appreciated feedback and support. Expressed concerns about staff shortage, financial worries, difficulties with work hours (night work) and the future of the profession.

Attributes: (a) professional growth in confidence and skills through experience and (b) passion for nursing.

Stress and frustration: (a) physical / mental changes (b) increased patient acuity / load, (c) constant change, and (d) time constraints.

to eed to avoid isolation and a sense of meaninglessness during retirement. Working for the satisfaction of connecting with patients and families also motivates older nurses. This satisfaction suggests that nurses' value their profession, even when they are discouraged by other factors. The factors that prompted older nurses to think about retiring were change and technology related factors. Learning assessments before implementing major technology
changes could focus on needs of the older group, including the need for more time and different methods of teaching. A technology support group for nurses 


\begin{tabular}{|c|c|c|}
\hline $\begin{array}{l}\text { Watson } \\
(2003) \\
\text { UK }\end{array}$ & $\begin{array}{l}\text { To investigate options, decisions and } \\
\text { outcomes for nurses aged } 50 \text { and over: } \\
\text { remaining, retiring returning to NHS }\end{array}$ & $\begin{array}{l}\text { Nurse advisors, } \\
\text { managers and policy } \\
\text { makers } n=18\end{array}$ \\
\hline $\begin{array}{l}\text { First author } \\
\text { Country } \\
\text { Year }\end{array}$ & Study aim & $\begin{array}{l}\text { Type (number) or } \\
\text { participants }\end{array}$ \\
\hline
\end{tabular}

\section{Mixed methods studies}

\begin{tabular}{|c|c|c|}
\hline $\begin{array}{l}\text { Clauson et } \\
\text { al. (2011) } \\
\text { Canada }\end{array}$ & $\begin{array}{l}\text { To describe the process and outcomes of } \\
\text { A Legacy Mentor (LM) pilot project, } \\
\text { including description of the projects } \\
\text { completed by the Legacy Mentors. }\end{array}$ & $\begin{array}{l}\text { Nurses } 55 \text { years and } \\
\text { older } n=29\end{array}$ \\
\hline $\begin{array}{l}\text { Clendon and } \\
\text { Walker } \\
\text { (2016) } \\
\text { New } \\
\text { Zealand }\end{array}$ & $\begin{array}{l}\text { To identify why some nurses cope well } \\
\text { with continuing to work as they age, and } \\
\text { others struggle. }\end{array}$ & $\begin{array}{l}\text { Nurses } 50 \text { years and } \\
\text { older } n=3273 \text { (survey) / } \\
n=46 \text { (interviews) }\end{array}$ \\
\hline $\begin{array}{l}\text { Dziadekwich } \\
\text { et al. (2012) } \\
\text { Canada }\end{array}$ & $\begin{array}{l}\text { To report an evaluation Retention of Older } \\
\text { workers (ROW) project and Older Worker } \\
\text { Leave (OWL) project }\end{array}$ & $\begin{array}{l}\text { Nurses } 50-60 \text { years } \\
n=15\end{array}$ \\
\hline $\begin{array}{l}\text { Klug (2009) } \\
\text { US }\end{array}$ & $\begin{array}{l}\text { To report the Impact of Baby Boomer } \\
\text { Nurses on Hospital Workforce Strategy_A } \\
\text { Case Study }\end{array}$ & $\begin{array}{l}\text { Children's nurses (44 } \\
\text { years and older) and } \\
\text { administrative } \\
\text { personnel } \\
\text { Survey }+\mathrm{n}=10 \\
\text { interviews }\end{array}$ \\
\hline $\begin{array}{l}\text { Utriainen et } \\
\text { al. (2015) } \\
\text { UK }\end{array}$ & $\begin{array}{l}\text { To describe the development process of a } \\
\text { theoretical model of ageing hospital } \\
\text { nurses' well-being at work and the } \\
\text { subsequent testing of the model itself. }\end{array}$ & $\begin{array}{l}\text { Nurses born between } \\
1948-1962 \\
N=328 \text { (survey) / } \mathrm{n}=21 \\
\text { (interviews) }\end{array}$ \\
\hline
\end{tabular}

\section{Literature, policy and structured reviews}

\begin{tabular}{|c|c|c|}
\hline $\begin{array}{l}\text { Graham and } \\
\text { Duffield } \\
\text { (2010) }\end{array}$ & $\begin{array}{l}\text { Literature review: To examine the impact } \\
\text { of ageing on individuals, the ageing } \\
\text { nursing workforce and the implications for } \\
\text { government policy given its status. }\end{array}$ & $\begin{array}{l}\text { Not reported } \\
\text { Not reported }\end{array}$ \\
\hline $\begin{array}{l}\text { Kwok et al. } \\
\text { (2016) }\end{array}$ & $\begin{array}{l}\text { Policy review: To identify gaps within } \\
\text { nursing collective agreements for } \\
\text { opportunities to implement practices to } \\
\text { sustain the nursing workforce }\end{array}$ & $\begin{array}{l}\text { Collective agreements }= \\
9 \\
\text { Practice policy }=5\end{array}$ \\
\hline
\end{tabular}

to ask questions and seek help easily with one-on-one interaction instead of over the phone support through the information technology desk would be helpful. Nurses should take time to reflect on their own values, life situation, and plans for retiring or continuing their career.

Stakeholders identified there should be policies related to older workers, but these were uncommon

Issues. pace of technological change; need for flexible working; professional development; caring responsibilities; physical fitness; stress; burnout; staffing evels; financial incentives to continue working; pensions do not suffer if nurses take a less senior role; need for one-to-one advice

Summary of the findings

Involving managers in the LM working group and as supporters provided an operational perspective to the process and structure of the overall project and the individual LM projects. Ensuring backfill for the LMs, facilitating staff buy-in and engagement, and articulating that the projects remained the property of Project staff could follow participant progress, offering coaching or assistance as needed. Although tracking participants about retirement was beyond the scope of the project, there was mixed response when participants were asked if the project had influenced career plans, ranging from already retired, to firm timelines being followed, to deciding to stay longer. Several commented that if they could continue teaching and mentoring, they would stay beyond 65 . Challenges for older nurses: physical workload, guilt from feelings of letting colleagues down; fears about cognitive ability; limited options for work able to undertake; new technology - little support; keeping up to date with professional development, academic education. Enablers for older nurses: keeping fit and looking after themselves; techniques to help memory (note pad); familiar work; colleague support; changing job roles; flexible working; adjusting environments (softer floors); reducing hours; having a choice about their job role and hours; resilience; feeling valued

OWL: flexible retirement; combat fatigue and stress $-55 \%$ of salary 12 weeks / year or 24 weeks / 2 years. Eligibility: 50 years or more, magic 80 (age plus years of service), worked at hospital for more than 5 years. Other projects: retirement planning education program: financial presentations, work-life balance programs, wellness programs; compressed workweek, mentoring newly graduated nurses). The OWL was reported as valuable to prepare for retirement; good for wellbeing, feeling rejuvenated. Long term effects yet to be evaluated Managers views: increased productivity; some increased workload and
resentment from other workers. $28 \%$ of nurses eligible did not participate: lack of management support; desire to retain security and seniority; economic hassle; decreased income.

Nurses stated that they face physical and mental challenges that need to be addressed for them to continue working. The primary concern is the ability to developed new strab egies to reain posible. Some admistrators reported mixed messages. Iongevity is appreciated but the organizalion has not erregic plan, for change to occur. Organisational barriers are difficult to overcome, and unless HR workfore plans are linked to the exective level strategic plan, retention may not be realized. Nurses top 5 priorities were: pensions and saving plans; flexible working (shorter shifts, job sharing); health insurance; opportunities to use talents and experience in new roles.

Ageing hospital nurses' well-being at work can be characterized as nurses' experience of collaboration, cooperation and togetherness with other nurses in supporting and caring workplace community, with the aim and possibility of high-quality patient care in a spirit where nurses and nursing are appreciated. ageing hospital nurses' well-being at work is linked to interaction between nurses as well as interaction between nurses and patients. Patient-care centeredness seems to be an important characteristic of practice for ageing hospital nurses providing well-being at work. Nursing managers and leaders need to take these factors into account in their work force and when managing ageing nurses with the aim of promoting their well-being at work and keeping experienced and highly skilled nurses on the job.

Shift workers over 40 years are at risk of fatigue and decreasing performance in the workplace, which has a negative impact on patient care. Older workers who feel they have been discriminated against are more likely to retire early, feel trapped in a workplace and reluctant to find a new workplace. There is a need for research into job redesign to address the issues of heavy workload and stress for older nurses. Older nurses could undertake specific roles focusing e cortic con cor senior health service managers are unknown. The collective agreement between 5 healthcare providers (2010) identified a need to address the retention, workload concerns and the anticipated nursin shortage. This initiative consists of three programmes that were implemented for the senior nurses who are eligible for retirement currently or in the near future: retention recognition (financial incentives), retirement preparation programme (job enrichment, including leadership assignments or special projects) and preretirement FTE reduction (opportunities for work-life balance). 


\begin{tabular}{|c|c|c|c|}
\hline $\begin{array}{l}\text { Ryan et al. } \\
\text { (2017) }\end{array}$ & $\begin{array}{l}\text { Structured review: To review the evidence } \\
\text { with regard to the specific challenges } \\
\text { encountered by older nurses in the } \\
\text { workplace. }\end{array}$ & $\begin{array}{l}14 \text { qualitative studies, } 3 \\
\text { quantitative studies, } 3 \\
\text { mixed methods studies }\end{array}$ & $\begin{array}{l}\text { The reviewed literature that attends to the 'vulnerable' aspects of ageing in relation to older nurses. Considerably less focus is on the positive experiences } \\
\text { and value of older nurses (such as, for example, enhanced expertise, maturity and empowerment through years of providing direct patient care). } \\
\text { Organisational directives tailored to older nurses should place a value on their service; respect their abilities and expertise; emphasise teamwork in clinical } \\
\text { practice; recognise the impact of a demanding working environment upon them and provide flexible working options. Supportive management should be } \\
\text { aware that older nurses may be more vulnerable to specific challenges, such as reduced physical and mental stamina or working through pain or injury, but } \\
\text { not conceptualise this as meaning that they do not have a significant value to the service. Efforts should be directed towards the development and evaluation } \\
\text { of organisational practices and policies to address these issues. }\end{array}$ \\
\hline $\begin{array}{l}\text { Stichler } \\
(2013)\end{array}$ & $\begin{array}{l}\text { Structured review: Describe challenges } \\
\text { and features to promote healthy } \\
\text { environments to motivate nurses to } \\
\text { continue working. }\end{array}$ & $\begin{array}{l}3 \text { SR, } 18 \text { quantitative, } 4 \\
\text { qualitative studies }\end{array}$ & $\begin{array}{l}\text { Physical challenges: Physical strain: equipment; walking distance; seating; computer workstations; lighting; Healthy environments: Reduce walking distance, } \\
\text { improve ergonomics of workstations; computers on wheels (nurses can access information without having to remember) }\end{array}$ \\
\hline $\begin{array}{l}\text { Uthaman et } \\
\text { al. (2016) }\end{array}$ & $\begin{array}{l}\text { Structured review: To determine the } \\
\text { existing evidence on challenges faced by } \\
\text { older nurses, factors which promote or } \\
\text { deter retirement and strategies that could } \\
\text { help in their retention }\end{array}$ & $\begin{array}{l}9 \text { literature reviews; } 4 \\
\text { quantitative studies; } 8 \\
\text { qualitative studies; } 1 \\
\text { mixed methods study }\end{array}$ & $\begin{array}{l}\text { Nurses in their mid-40's report sensory limitations (vision and hearing); weight problems (weight gain); physical neck, back, shoulder pain; arthritis; reading, } \\
\text { medication and manual handling difficulties; discomfort working with computers; shift work more tiring. } \\
\text { Nurses retired for financial reasons; gained financial security; optimal pension; health concerns; caring responsibilities; not being valued; rapid technology } \\
\text { changes; decreased stamina; stress. Nurses valued being recognised for their work; preferred managers who are professional, demonstrate integrity and } \\
\text { empower others; ongoing professional development opportunities; wanted to keep up with changes; reduction in workload; less physical demanding jobs; } \\
\text { flexible workload; compensation for years of experience, knowledge and responsibility; financial benefits; patient contact and interpersonal relationships; } \\
\text { work satisfaction; valued by senior managers; supported by colleagues. Nurses would consider working until } 65 \text {, especially if their partners and friends' } \\
\text { decisions to keep working. } \\
\text { Recommendations: ergonomically designed environments; phased-in retirement plans; flexible working (job sharing, shorter shifts, casual hours); supportive } \\
\text { line mangers; educational and development opportunities; respect and recognition; redesign jobs; job rotation; mentor new nurses; career breaks; carers } \\
\text { leave. The review reported a lack of empirical testing of interventions for late career nurses. }\end{array}$ \\
\hline
\end{tabular}


Table 2: Mechanisms of change underpinning the Nottingham Legacy Nurse Programme

Community of Promotes an ethos of learning and practice-based knowledge development Practice through active engagement within a Community of Practice (CoP) where members are motivated to develop a sense of identity and belonging (Wenger, 1998).

Feeling valued Learning arises out of the act of social participation and evolves through continued and supported engagement and collaboration (Andrew et al., 2008). Young and Mitchell (2003) identify CoP's as a valuable resource to transfer knowledge and skills within organisations. Andrew et al. (2008) suggest that nurse CoP's can challenge and change outdated care practices and disseminate new knowledge.

\section{Employee Engagement}

Empowering, energising and engagement
Derived from organisational psychology research, which includes:

- proactive behaviour / personal initiative: taking initiative in improving current circumstances or creating new ones (Crant, 2000; Frese and Fay, 2001)

- organisational citizenship: individual behaviour that is discretionary, not directly or explicitly recognised by the formal reward system, and that in the aggregate promotes the effective functioning of the organization (Organ et al., 2005).

- contextual performance focuses on the goals of the organisation (Organ et al., 2005; West and Dawson, 2012). An engaged employee is more likely to display these behaviours, which will contribute to the effectiveness and health of the organisation above and beyond their core job roles. The King's Fund (West and Dawson, 2012) outline the elements of employee engagement:

- psychological engagement (a positive, fulfilling, work-related state of mind)

- proactivity, enthusiasm and initiative

- organisational citizenship behaviours and organisational commitment

- involvement in decision-making

- positive representation of the organisation to outsiders.

\section{Coaching}

Encouragement, support and confidence building
Carey et al. (2011) conducted an iterative literature review which identified key elements of leadership development coaching models:

- Relationship building involves creating an open, trusting, non-judgmental and supportive environment. The coach demonstrates empathy, objectivity and an interest in the wellbeing of the individual. The development of the relationship over time will instil and maintain positive behaviour change.

- Problem defining and goal setting: Feedback of the individual is accessed from peers, patients and managers, using instruments such as 360-degree assessment. Feedback stimulates reflection, develop self-awareness and challenge irrational thoughts that inhibit successful performance.

- Problem solving developing of action plans to address specific goals. Problem solving tools often include role playing, visualisation, reading material, and dialogue to help develop needed skills and attitudes.

- Transformation process: Behaviour change is achieved through selfawareness, understanding of behaviours that affect performance and generating new perceptions. The individual becomes aware of the consequences of their actions.

Outcomes: maintain focus on behaviour change by creating and implementing action plans and setting goals. Seeing achievement is re-energising and motivates creativity and action. The expected outcomes include personal performance, adding value to the organisation, and for the organisation to become more successful. 


\section{Table 3: Nottingham Legacy Nurse Programme design - key components}

The programme will be active for a minimum of six months with participants spending at least one full day per week on the education improvement project. Organisations may choose to extend the programme and set their own criteria for completion.

\begin{tabular}{|c|c|c|c|}
\hline Trained facilitator & \multicolumn{3}{|c|}{$\begin{array}{l}\text { Skilled trained facilitator: facilitator trained in peer group facilitation; coaching; } \\
\text { engagement; and leadership } \\
\text { Possible co-facilitation by a Legacy Nurse / Midwife who has completed the } \\
\text { programme and facilitator training }\end{array}$} \\
\hline Candidates & \multicolumn{3}{|c|}{$\begin{array}{l}\text { Organisations develop recruitment strategies ensuring all eligible nurses and } \\
\text { midwives have an opportunity to participate }\end{array}$} \\
\hline $\begin{array}{l}\text { Programme } \\
\text { components }\end{array}$ & Desired outcomes & Models / Theory & Evaluation \\
\hline $\begin{array}{l}\text { Regular group meetings: } \\
\text { discussion groups, } \\
\text { workshops, } \\
\text { presentations. }\end{array}$ & $\begin{array}{l}\text { - Develop supportive energised } \\
\text { practice communities } \\
\text { - Develop a common purpose } \\
\text { of the Legacy Programme } \\
\text { - Share resources and } \\
\text { inspiration } \\
\text { - Establish clinical networks } \\
\text { with the wider nursing clinical } \\
\text { / educational workforce to } \\
\text { share ideas and knowledge }\end{array}$ & $\begin{array}{l}\text { - Community of } \\
\text { Practice (Wenger, } \\
\text { 1998) } \\
\text { - Peer support models }\end{array}$ & $\begin{array}{l}\text { - Programme } \\
\text { evaluation } \\
\text { - Retention within the } \\
\text { cohort } \\
\text { - Project specific } \\
\text { outcomes }\end{array}$ \\
\hline $\begin{array}{l}\text { Project work focused on } \\
\text { individual's clinical } \\
\text { areas }\end{array}$ & $\begin{array}{l}\text { - Knowledge transfer } \\
\text { - Improve clinical care / } \\
\text { outcomes } \\
\text { - Develop a sense of } \\
\text { ownership, autonomy, } \\
\text { empowerment and } \\
\text { professional pride. } \\
\text { - Skills development, builds } \\
\text { confidence: teaching / } \\
\text { mentoring / clinical reasoning } \\
\text { / leadership / audit and } \\
\text { evidence-based practice / } \\
\text { decision making } \\
\text { - Appreciation for their } \\
\text { contribution and expertise. } \\
\text { - Enhanced learner experience } \\
\text { practice learning environment }\end{array}$ & $\begin{array}{l}\text { - Employee } \\
\text { engagement models: } \\
\text { - West and Dawson } \\
\text { (2012) } \\
\text { - University of Bath } \\
\text { and The NHS Staff } \\
\text { Council (2014) } \\
\text { - Robinson et al. } \\
\text { (2004) }\end{array}$ & $\begin{array}{l}\text { - Staff wellbeing and } \\
\text { satisfaction (staff and } \\
\text { student surveys) } \\
\text { - Staff retention } \\
\text { - Project outcomes } \\
\text { (e.g. clinical outcomes } \\
\text { and audit, team } \\
\text { performance, practice } \\
\text { learning environment } \\
\text { assessment, team } \\
\text { retention) }\end{array}$ \\
\hline $\begin{array}{l}\text { Individual support from } \\
\text { trained facilitators }\end{array}$ & $\begin{array}{l}\text { - Access to careers coaching } \\
\text { for individual participants. } \\
\text { - Improve retention of late } \\
\text { career nurses } \\
\text { - Recruit experienced late } \\
\text { career nurses into different } \\
\text { clinical areas and roles. } \\
\text { - Improve psychosocial and } \\
\text { physical wellbeing of late } \\
\text { career nurses }\end{array}$ & $\begin{array}{l}\text { - Coaching } \\
\text { frameworks: GROW, } \\
\text { AHEAD STRIDE }\end{array}$ & $\begin{array}{l}\text { - Staff development } \\
\text { - Career progression } \\
\text { - Staff wellbeing } \\
\text { - Retention }\end{array}$ \\
\hline
\end{tabular}


Table 4. The NLNP: RE-AIM framework components

\begin{tabular}{|c|c|c|}
\hline & Components and core questions & Considerations and suggestions \\
\hline \multirow[t]{2}{*}{ Adoption } & $\begin{array}{l}\text { Organisations: health and social care } \\
\text { organisations: primary and community care, } \\
\text { acute care and mental health settings }\end{array}$ & $\begin{array}{l}\text { Participants: late career nursing, midwifery and } \\
\text { allied healthcare workforce. Employers who wish to } \\
\text { improve retention of late career workforce and } \\
\text { facilitate knowledge transfer }\end{array}$ \\
\hline & $\begin{array}{l}\text { Conduct initial scoping to assess the } \\
\text { interest of senior staff and late career } \\
\text { nurses and midwives. }\end{array}$ & $\begin{array}{l}\text { Monitoring and evaluation: programme uptake, } \\
\text { compliance and the degree to which the programme } \\
\text { was delivered as planned (programme fidelity, } \\
\text { process evaluation) }\end{array}$ \\
\hline \multirow[t]{2}{*}{ Reach } & $\begin{array}{l}\text { Target population } \\
\text { Individuals: experienced nurses and } \\
\text { midwives who would consider remaining } \\
\text { within their organisation if they had } \\
\text { opportunity to access the programme. } \\
\text { Organisations: wanting to develop ways to } \\
\text { facilitate knowledge transfer, value the } \\
\text { experience of late career staff and improve } \\
\text { retention of the late career cohort. }\end{array}$ & $\begin{array}{l}\text { Promotion: advertisement, engagement days, } \\
\text { recruitment fares and staff appraisals. Late career } \\
\text { options should be introduced in early and mid- } \\
\text { careers as part of a career planning. Asking } \\
\text { applicants how they heard about the programme to } \\
\text { help identify the most effective method of } \\
\text { promotion. Develop strategies to improve inclusion } \\
\text { of staff from BAME backgrounds (local champions) }\end{array}$ \\
\hline & $\begin{array}{l}\text { Share learning and disseminate pilot } \\
\text { programme outcomes across clinical and } \\
\text { social care organisations to various } \\
\text { stakeholder groups (publications, } \\
\text { presentations, posters, newsletters) }\end{array}$ & \\
\hline \multirow[t]{2}{*}{$\begin{array}{l}\text { Implementati } \\
\text { on }\end{array}$} & $\begin{array}{l}\text { Further piloting in different sites and } \\
\text { settings is required. This will identify how } \\
\text { the programme can be refined and adapted } \\
\text { for different settings (i.e. smaller groups for } \\
\text { primary care sites) }\end{array}$ & $\begin{array}{l}\text { Consider facilitator training and ability to deliver the } \\
\text { programme. Assessment of the programme fidelity, } \\
\text { identify adaptations, barriers and facilitators. } \\
\text { Conduct a cost-benefit analysis of the programme } \\
\text { as part of the pilot study. }\end{array}$ \\
\hline & & $\begin{array}{l}\text { Continually monitored to identify improvements or } \\
\text { revisions to respond to the changing context }\end{array}$ \\
\hline \multirow[t]{2}{*}{ Effectiveness } & $\begin{array}{l}\text { Programme outcomes: } \\
\text { Individual: wellbeing, satisfaction, retention, } \\
\text { programme acceptability, benefits, skills } \\
\text { development, confidence. } \\
\text { Clinical areas: student evaluations of } \\
\text { practice areas, staff retention, patient } \\
\text { outcomes (related to individual projects or } \\
\text { teams), morale. }\end{array}$ & $\begin{array}{l}\text { Baseline, mid-point, post programme and longer } \\
\text { terms evaluations of outcomes should include } \\
\text { qualitative and quantitative data and incorporate } \\
\text { findings from regional / national data sets where } \\
\text { possible (Staff Surveys). Impact assessments of the } \\
\text { programme should also capture the impact of } \\
\text { individual projects and role development. }\end{array}$ \\
\hline & $\begin{array}{l}\text { Organisation outcomes: retention, staff and } \\
\text { patient satisfaction and outcomes, cost- } \\
\text { benefit (see four key learning themes RCN } \\
\text { 2016; Indicators of nurse retention Buchan } \\
\text { et al. 2018) }\end{array}$ & $\begin{array}{l}\text { Identify ways to remain in contact with Legacy } \\
\text { Nurses and midwives to enable long term } \\
\text { evaluation (career progression, leaving or remaining } \\
\text { in in employment) }\end{array}$ \\
\hline
\end{tabular}




\section{References}

Andrew N, Tolson D and Ferguson D (2008) Building on Wenger: communities of practice in nursing. Nurse Educ Today 28(2): 246-252.

Andrews J, Manthorpe J and Watson R (2005) Employment transitions for older nurses: a qualitative study. J Adv Nurs 51(3): 298-306.

Arksey H and O'Malley L (2005) Scoping studies: towards a methodological framework. International Journal of Social Research Methodology 8(1): 19-32.

Aromataris E and Munn ZE (2020) JBI Manual for Evidence Synthesis. Available at: https://synthesismanual.jbi.global. https://doi.org/10.46658/JBIMES-20-01 (accessed 21.5.21).

Bailey S and West M (2020) Covid-19: why compassionate leadership matters in a crisis. Available at: https://www.kingsfund.org.uk/blog/2020/03/covid-19-crisis-compassionate-leadership (accessed 21.5.21).

Blakeley JA and Ribeiro VE (2008) Early retirement among registered nurses: contributing factors. J Nurs Manag 16(1): 29-37.

Borneo A, Dalrymple A, Hadden C, Johnson A, Kiely S, Knape J, et al. Building a Better Future for Nursing: RCN members have their say. Report No.009 366, (Royal College of Nursing, London, UK, 2020).

Buchan J, Shaffer F and Catton H. Policy Brief: Nurse Retention. (The International Centre on Nurse Migration, Philadelphia. US, 2018).

Burdett Trust for Nursing, World Health Organisation and International Council of Nurses (2019) Nursing Now. Available at: https://www.nursingnow.org (accessed 21.5.21).

Carey W, Philippon DJ and Cummings GG (2011) Coaching models for leadership development: An integrative review. Journal of Leadership Studies 5(1): 51-69.

Clauson M, Wejr P, Frost L, McRae C and Straight H (2011) Legacy Mentors: translating the wisdom of our senior nurses. Nurse Educ Pract 11(2): 153-158.

Clendon J and Walker L (2013a) The health of nurses aged over 50 in New Zealand. Contemporary Nurse 45(1): 85-94.

Clendon J and Walker L (2013b) Nurses aged over 50 years and their experiences of shift work. Journal of Nursing Management 21(7): 903-913.

Clendon J and Walker L (2016) Nurses aged over 50 and their perceptions of flexible working. J Nurs Manag 24(3): 336-346.

Crant JM (2000) Proactive Behavior in Organizations. Journal of Management 26(3): 435-462.

Creswell JW, Fetters MD and Ivankova NV (2004) Designing a mixed methods study in primary care. Annals of family medicine 2(1): 7-12.

Doran D, Jeffs L, Rizk P, Laporte DR, Chilcote AM and Bai YQ (2015) Evaluating the late career nurse initiative: a cross-sectional survey of senior nurses in Ontario. J Nurs Manag 23(7): 859-867.

Duffield C, Graham E, Donoghue J, Griffiths R, Bichel-Findlay J and Dimitrelis S (2015) Why older nurses leave the workforce and the implications of them staying. J Clin Nurs 24(5-6): 824-831.

Durosaiye IO, Hadjri K and Liyanage CL (2016) Identifying Challenging Job and Environmental Demands of Older Nurses Within the National Health Service. Herd 9(3): 82-105.

Dziadekwich R, Andrushko K and Klassen K (2012) A new approach to retaining older workers. Can Nurse 108(6): 18-20.

Falk NL, Rudner N, Chapa D and Greene J (2017) Nurse practitioners and intent to retire. Journal of the American Association of Nurse Practitioners 29(3).

Frese M and Fay D (2001) 4. Personal initiative: An active performance concept for work in the 21st century. Research in Organizational Behavior 23: 133-187.

Friedrich LA, Prasun MA, Henderson L and Taft L (2011) Being a seasoned nurse in active practice. Journal of Nursing Management 19(7): 897-905.

Glasgow RE, Harden SM, Gaglio B, Rabin B, Smith ML, Porter GC, et al. (2019) RE-AIM Planning and Evaluation Framework: Adapting to New Science and Practice With a 20-Year Review. Frontiers in Public Health $7(64)$.

Graham E, Donoghue J, Duffield C, Griffiths R, Bichel-Findlay J and Dimitrelis S (2014) Why do older RNs keep working? J Nurs Adm 44(11): 591-597.

Graham EM and Duffield C (2010) An ageing nursing workforce. Aust Health Rev 34(1): 44-48. 
Health Education England. RePAIR: Reducing Attrition and Improving Retention. (Health Education England, Leeds, UK, 2018).

House of Commons Health Committee. The nursing workforce: Second Report of Session 2017-19. . (House of Commons, London, UK, 2018).

Jeffs L, Nincic V, Hayes L, Jerome D and Malecki V (2014) Insights from nurse leaders to optimize retaining late career nurses. Nurs Leadersh (Tor Ont) 27(3): 29-39.

Jones K, Warren A and Davies A. Mind the Gap: Exploring the needs of early career nurses and midwives in the workplace. Summary report from Birmingham and Solihull Local Education and Training Council Every Student Counts Project. (Health Education England, Leeds, UK, 2015).

King's Fund (2018) The healthcare workforce in England: Make or break? Available at: https://www.kingsfund.org.uk/publications/health-care-workforce-england (accessed 21.5.21).

King's Fund (2020) Urgent action is needed to improve working conditions for nurses and midwives. London UK: The King's Fund.

Klug SH (2009) Recruit, respect, and retain: the impact of baby boomer nurses on hospital workforce strategy--a case study. Creat Nurs 15(2): 70-74.

Kovner CT, Brewer CS, Cheng Y and Djukic M (2007) Work attitudes of older RNs. Policy, Politics, \& Nursing Practice 8(2): 107-119.

Kwok C, Bates KA and Ng ES (2016) Managing and sustaining an ageing nursing workforce: identifying opportunities and best practices within collective agreements in Canada. Journal of Nursing Management 24(4): 500-511.

Letvak S (2003a) The experience of being an older perioperative nurse. Aorn j 78(4): 635-649.

Letvak S (2003b) The experience of being an older staff nurse. West J Nurs Res 25(1): 45-56.

Levac D, Colquhoun H and O'Brien KK (2010) Scoping studies: advancing the methodology. Implementation Science 5(1): 69.

Li YIN and Jones CB (2013) A literature review of nursing turnover costs. Journal of Nursing Management 21(3): 405-418.

Liebermann SC, Müller A, Weigl M and Wegge J (2015) Antecedents of the expectation of remaining in nursing until retirement age. Journal of Advanced Nursing 71(7): 1624-1638.

NHS Digital (2019) NHS Workforce Statistics - June 2019. Available at: https://digital.nhs.uk/data-andinformation/publications/statistical/nhs-workforce-statistics/june-2019 (accessed 21.5.21).

NHS Employers (2017) An ageing workforce - the key issues. Available at: https://www.nhsemployers.org/retention-and-staff-experience/supporting-older-workers/workinglonger-group-tools-and-resources/the-ageing-workforce-a-resource-for-staff-and-theirrepresentatives/an-ageing-workforce-the-key-issues (accessed 21.5.21).

NHS England (2019a) 2019 National NHS Staff Survey. Available at:

https://www.england.nhs.uk/statistics/2020/02/18/2019-national-nhs-staff-survey (accessed 21.5.21).

NHS England. NHS Interim People Plan (NHS Employers, London, UK, 2019b).

NHS England. The NHS Long Term Plan. (NHS England, London, UK, 2019c).

NHS England. People Plan for 2020/2021. (NHS England, London, UK, 2020).

NHS Improvement. Developing people Improving Care. (NHS Improvement, London, UK, 2016).

Novick G, Reid AE, Lewis J, Kershaw TS, Rising SS and Ickovics JR (2013) Group prenatal care: model fidelity and outcomes. Am J Obstet Gynecol 209(2): 112.e111-116.

Nursing and Midwifery Council. The NMC register 2012/13-2016/17. (Nursing and Midwifery Council, London, UK, 2017).

Nursing and Midwifery Council. Leavers Survey 2019. (Nursing and Midwifery Council, London, UK, 2020).

Organ D, Podsakoff P and MacKenzie S (2005) Organizational Citizenship Behaviour: Its nature, antecedents, and consequences. Beverly Hills, CA: Sage Publications.

Palumbo MV, Mclntosh B, Rambur B and Naud S (2009) Retaining an aging nurse workforce: perceptions of human resource practices. Nurs Econ 27(4): 221-227, 232.

Perlo J, Balik B, Swensen S, Kabcenell A, Landsman J and Feeley D. IHI Framework for Improving Joy in Work. IHI White Paper. (Institute for Healthcare Improvement, Cambridge, Massachusetts, 2017).

Public Health England. East Midlands Profile A summary of public health in the region 2018. (Public Health England, 2018).

Robinson D, Perryman S and Hayday S. The Driver of Employee Engagement. (Institute for Employment Studies, Brighton, UK, 2004).

Ross S, Jabbal J, Chauhan K, Maguire D, Randhawa M and Dahir S. Workforce race inequalities and inclusion in NHS providers. (The King's Fund, London, UK, 2020). 
Royal College of Midwives. State of Maternity Services Report 2016. (Royal College of Midwives, London, UK, 2017).

Royal College of Nursing. Valuing older workers: A 10 step action plan for working in partnership to create a learning culture that supports staff who work later in life. (Royal College of Nursing, London, UK., 2016).

Royal College of Nursing. Employment Survey 2019. (Royal College of Nursing, London, UK, 2019).

Ryan C, Bergin M and Wells JS (2017) Valuable yet Vulnerable-A review of the challenges encountered by older nurses in the workplace. Int J Nurs Stud 72: 42-52.

Spiva L, Hart P and McVay F (2011) Discovering Ways That Influence the Older Nurse to Continue Bedside Practice. Nursing Research and Practice 2011: 840120.

Stichler JF (2013) Healthy work environments for the ageing nursing workforce. J Nurs Manag 21(7): $956-963$.

Storey C, Cheater F, Ford J and Leese B (2009) Retaining older nurses in primary care and the community. Journal of Advanced Nursing 65(7): 1400-1411.

Thorpe R, Gold J and Lawler J (2011) Locating Distributed Leadership. International Journal of Management Reviews 13(3): 239-250.

University of Bath and The NHS Staff Council. NHS Working Longer Review: Audit of Existing Research. (NHS Employers, London, UK, 2014).

Uthaman T, Chua TL and Ang SY (2016) Older nurses: A literature review on challenges, factors in early retirement and workforce retention. Proceedings of Singapore Healthcare 25: 50 - 55.

Utriainen K, Ala-Mursula L and Kyngäs H (2015) Hospital nurses' wellbeing at work: a theoretical model. Journal of Nursing Management 23(6): 736-743.

Valencia D and Raingruber B (2010) Registered nurses' views about work and retirement. Clin Nurs Res 19(3): 266-288.

Watson Rea (2003) Older Nurses and Employment Decisions. Nursing Standard 18(6): 35-40.

Wenger E (1998) Communities of Practice: Learning Meaning and Identity, sixth ed. Cambridge, UK: Cambridge University Press.

West M, Bailey S and Williams E. The courage of compassion: Supporting nurses and midwives to deliver highquality care. (The King's Fund, London, UK, 2020).

West $\mathrm{M}$ and Dawson J. Employee engagement and NHS performance. (The Kings Fund, London, UK, 2012).

Young S and Mitchell J (2003) Putting more practice into communities of practice. In: Australian Vocational Education and Training Research Association (AVETRA) Conference, Australian Technology Park, Sydney. 